\title{
The Nucleosome Remodeling and Deacetylase Chromatin Remodeling (NuRD) Complex Is Required for Peripheral Nerve Myelination
}

\author{
Holly Hung, ${ }^{1,3}$ Rebecca Kohnken, ${ }^{3}$ and John Svaren ${ }^{2,3}$ \\ ${ }^{1}$ Cellular and Molecular Pathology Graduate Program, ${ }^{2}$ Department of Comparative Biosciences, ${ }^{3}$ Waisman Center, University of Wisconsin-Madison, \\ Madison, Wisconsin 53705
}

Several key transcription factors and coregulators important to peripheral nerve myelination have been identified, but the contributions of specific chromatin remodeling complexes to peripheral nerve myelination have not been analyzed. Chromodomain helicase DNAbinding protein 4 (Chd4) is the core catalytic subunit of the nucleosome remodeling and deacetylase (NuRD) chromatin remodeling complex. Previous studies have shown Chd4 interacts with Nab (NGFI-A/Egr-binding) corepressors, which are required for early growth response 2 (Egr2/Krox20), to direct peripheral nerve myelination by Schwann cells. In this study, we examined the developmental importance of the NuRD complex in peripheral nerve myelination through the generation of conditional Chd4 knock-out mice in Schwann cells (Chd4 ${ }^{\text {loxPloxP }}$; P0-cre). Chd4 conditional null mice were found to have delayed myelination, radial sorting defects, hypomyelination, and the persistence of promyelinating Schwann cells. Loss of Chd4 leads to elevated expression of immature Schwann cell genes (Id2, c-Jun, and p75), and sustained expression of the promyelinating Schwann cell gene, 0ct6/Scip, without affecting the levels of Egr2/Krox20. Furthermore, Schwann cell proliferation is upregulated in Chd4-null sciatic nerve. In vivo chromatin immunoprecipitation studies reveal recruitment of Chd4 and another NuRD component, Mta2, to genes that are positively and negatively regulated by Egr2 during myelination. Together, these results underscore the necessity of Chd4 function to guide proper terminal differentiation of Schwann cells and implicate the NuRD chromatin remodeling complex as a requisite factor in timely and stable peripheral nerve myelination.

\section{Introduction}

In the peripheral nervous system, Schwann cells produce the lipid-rich myelin sheath that envelops axons and provides trophic support vital to nerve development and saltatory propagation of action potentials (Nave and Trapp, 2008). Defects in peripheral myelination underlie one of the most common inherited neurological disorders, Charcot-Marie-Tooth disease (Scherer and Wrabetz, 2008). Maturation of Schwann cells is associated with both activation of a myelin-associated gene network and simultaneous repression of genes that mark the earlier stages of development (Jessen and Mirsky, 2008). One of the major factors regulating myelination is the zinc-finger transcription factor, early growth response-2 (Egr2/Krox20). Analysis of

Received June 8, 2011; revised Nov. 11, 2011; accepted Nov. 24, 2011.

Author contributions: H.H. and J.S. designed research; H.H. and R.K. performed research; H.H., R.K., and J.S. analyzed data; H.H. and J.S. wrote the paper.

This work was supported by National Institutes of Health Grant HD41590 (J.S.) and National Institute of Child Health and Human Development Grant P30 HD03352 (core grant to the Waisman Center). We thank Albee Messing and Katja Georgopoulos for generously providing the PO-CRE and the Chd4 floxed mice, respectively; Camila LopezAnido for mouse work assistance; Paul Wade for a Chd4 antibody; Dies Meijer for 0ct6 antibodies; and Karla Knobel, the University of Wisconsin Electron Microscope Facility, and David Gamm for providing microscopy resources.

The authors declare no competing financial interests.

Correspondence should be addressed to Dr. John Svaren, Waisman Center, University of Wisconsin-Madison, 1500 Highland Avenue, Madison, WI 53705. E-mail: jpsvaren@wisc.edu.

DOI:10.1523/JNEUROSCI.2895-11.2012

Copyright $\odot 2012$ the authors $\quad 0270-6474 / 12 / 321517-11 \$ 15.00 / 0$
Egr2/Krox20-deficient mice revealed an arrest at the promyelinating stage of Schwann cell development, and it is also required for maintenance of the myelin sheath in adulthood (Topilko et al., 1994; Le et al., 2005a; Decker et al., 2006). Egr2 target genes include several lipid biosynthetic genes and major myelin components, including myelin protein zero $(M p z)$ and peripheral myelin protein 22 (Pmp22) (Nagarajan et al., 2001). The activity of Egr2 requires interaction with the NGFI-A/Egr binding protein (Nab1 and Nab2) transcriptional coregulators (Le et al., 2005b; Desmazières et al., 2008; Baloh et al., 2009), which directly bind and repress Egr2 transcriptional activity (Russo et al., 1995; Svaren et al., 1996).

Establishment and maintenance of gene expression patterns depend upon epigenetic regulation, and studies of histone deacetylase (HDAC) function in oligodendrocytes and Schwann cells have highlighted their importance during myelination (Marin-Husstege et al., 2002; Ye et al., 2009; Liu and Casaccia, 2010; Chen et al., 2011; Jacob et al., 2011). Histone deacetylase activity is necessary for oligodendrocyte lineage progression, and Hdac1/Hdac2 control the transcriptional program of myelination and the survival of Schwann cells. Although histone deacetylases are often recruited to genes as components of larger chromatin remodeling complexes such as the Sin3a, CoREST, or NuRD complexes, the role of a specific chromatinremodeling complex in peripheral nerve myelination has not been characterized. 
Investigations into the molecular mechanism of Nab repression revealed two independent repression domains, one of which interacts with chromodomain helicase DNA-binding protein 4 (Chd4) (Mi2 $\beta$ ) (Srinivasan et al., 2006; Mager et al., 2008). Chd4 catalyzes ATP-dependent nucleosome remodeling as part of the nucleosome remodeling and deacetylase (NuRD) complex (Denslow and Wade, 2007; Marfella and Imbalzano, 2007). The enzymatic activities of NuRD subunits combine chromatin remodeling, and histone deacetylation through the Hdac1/2 subunits of the NuRD complex. Although the NuRD complex was originally characterized as a repressive chromatin remodeling complex, it has also been found to promote gene expression (Williams et al., 2004; Yoshida et al., 2008; Miccio and Blobel, 2010). In this study, we have tested whether NuRD activity is required for peripheral nerve myelination by analyzing the morphological and gene expression defects caused by Schwann cellspecific ablation of Chd4.

\section{Materials and Methods}

Generation of mutant mice and genotyping. Mi- $2 \beta^{\text {LoxP/LoxP }}$ mice (designated as Chd4 $4^{\text {loxP/loxP }}$ ) (Williams et al., 2004) and $\mathrm{mP}_{0}$ TOTA(Cre) mice (designated as P0-cre transgenic mice) (Feltri et al., 1999) were bred and maintained under specific pathogen-free conditions with ad libitum food and water. To generate Chd4 mutant mice (Chd $4^{\text {loxP/loxP }} ; \mathrm{P} 0$-cre), female $C h d 4^{\text {loxP/+ }}$; P0-cre mice were mated with male Chd4 $4^{\text {loxP/loxP }}$ mice. Genomic DNA from the resulting offspring was analyzed by PCR for the Cre transgene and the $C h d 4^{\text {loxP } / \text { loxP }}$ allele. Chd $4^{\text {loxP } / \text { loxP }}$ mice were used as controls in these experiments (control Chd 4 mice). All experiments were performed in strict accordance with experimental protocols approved by the University of Wisconsin School of Veterinary Medicine (Madison, WI). The founder mouse containing the $\mathrm{P} 0$-cre transgene was maintained on a FVB/N background (Feltri et al., 1999) and founder Chd4 $4^{\text {loxPlloxP }}$ was maintained on a 129/C57BL/6 mixed background. Hence, mice used in experiments contained a $\mathrm{F}_{2}$ mixed genetic background. Genotyping primer sequences are as follows: Chd4, forward, sense, $5^{\prime}$-CTC CAG AAG AAG ACG GCA GAT CT-3'; Chd4, reverse, antisense, 5'-GTC CTT CCA AGA GAG AGC AAG-3'; KG4R, antisense, $5^{\prime}$-CTT CCA CTG TGA CGT CCA GAC GCA-3'; mP0, 5' -CCA CCA CCT CTC CAT TGC AC-3'; Cre-2r, 5'-CAC GAC CGG CAA ACG GAC AGA AG-3'.

Accelerating Rotarod test. Mice were trained and tested using a $1 \mathrm{~d}$ train/test regimen on a MED Associates ENV-575M Rotarod with an acceleration speed from 4 to $40 \mathrm{rpm}$ in $300 \mathrm{~s}$. Mice were placed on the rod rotating at $4 \mathrm{rpm}$. The rotation rate was then increased at $0.12 \mathrm{rpm} / \mathrm{s}$ to determine the latency time until the mice fell off the rod. Each mouse received one training session and then three trials with 20 min between each trial. At least five mice from each genotype were analyzed at each time point. All data were analyzed using ANOVA.

Quantitative RT-PCR. For the developmental time points (P8, P15, and P30), RNA was purified using RNeasy Lipid Tissue Mini Kit (QIAGEN) according to the manufacturer's directions from sciatic nerves of Chd4 mutant and control mice. One microgram of total RNA from each sample was used to prepare cDNA as described previously (Lee et al., 1996). Quantitative RT-PCR was performed using Power SYBR Green Assays on the TaqMan Step One Plus detection system (Applied Biosystems). Relative amounts of each gene between samples were determined using the comparative Ct method (Livak and Schmittgen, 2001) and normalized to the relative levels of $18 \mathrm{~S}$ rRNA. Primers used for analysis are included in Table 1.

Immunohistochemistry and Western blotting. For immunohistochemical analysis of sciatic nerve, freshly dissected nerves were embedded in Tissue-Tek OCT compound (Sakura Finetek) and cut into $5 \mu \mathrm{m}$ cryostat sections. For fluorescence immunohistochemistry, the sections were fixed for $15 \mathrm{~min}$ in $4 \%$ paraformaldehyde and then blocked in 5\% goat serum $/ 1 \%$ BSA for $1 \mathrm{~h}$ at room temperature. Incubation with primary antibody was performed overnight at $4^{\circ} \mathrm{C}$ in blocking solution, and secondary antibody incubation was performed at room temperature for $1 \mathrm{~h}$. For Western immunoblotting, sciatic nerves were homogenized in lysis
Table 1. List of mouse primers used in qRT-PCR experiments

\begin{tabular}{lll}
\hline Gene & Forward & Reverse \\
\hline Egr2 & TGC TAG CCC TTT CCG TTG A & TCT TTT CCG CTG TCC TCG AT \\
Nab2 & ACC AGCCCC TTA GAG GCC T & TAC ACA ATC TGA AAA GAA AGA CA \\
Sox10 & GCC ACG AGG TAA TGT CCA ACA & TGG TCC AGC TCA GTC ACA TCA \\
Oct6 & CTG AGC TTC AAG AAC ATG TGC AA & GCG ATC TTG TCC AGG TTG GT \\
Hmgcr & GGA TGG TAC CGG TGC TCT & AGA AAC GAA CTG TAG CTC \\
Sqle & GGC TTG AAG AGG ATG TAT ATA GCA TA & GTC CAC TGT GGA AGT GAC ACA GTT \\
Cx32 & ACC GCC TCT CAC CTG AAT ACA & CTC GCT CAG CAG CTT GTT GAT \\
Mpz & CCC TGG CCA TTG TGG TTT AC & CCA TTC ACT GGA CCA GAA GGA G \\
Id2 & ACC ACC CTG AAG ACG GAC AT & GAA TTC AGA CGC CTG CAA GG \\
C-Jun & CGG CTA CAG TAA CCC TAA GAT CCT & GCC AGG TTC AAG GTC ATG CT \\
Egr1 & TGA AAC AGC CAT GTC CAA GTTC & AGG GCC AGG CAT GTG ATG \\
Ngfr/p75 & AGG TCG AGA AGC TGC TCA ATG & AGG CCT CGT GGG TAA AGG A \\
Sox2 & AAA TCT CCG CAG CGA AACG & TTT GGA TGG GAT TGG TGG TT \\
L1cam & CTC CTG CTG CCT CCT TCT CTT & TTC AAT GAG GAT GGC TCT TTC A \\
Notch1 & ACT TGG TGG GCA GCA GAT G & TGC CGA ACC AGT AGC TCC TAA \\
Pmp22 & GGC AAT GGA CAC ACG ACT GA & GCT CCC AAG GCG GAT GT \\
\hline
\end{tabular}

buffer (0.25 м Tris- $\mathrm{HCl}, \mathrm{pH}$ 6.8, 20\% glycerol, 4\% SDS, $10 \%$ $\beta$-mercaptoethanol). The protein lysates were fractionated on a SDSPAGE gel and transferred to nitrocellulose. The primary antibodies used were rabbit anti-Scip (1:1000; kind gift from D. Meijer, Rotterdam, the Netherlands), rabbit anti-Egr2/Krox20 (1:1000; Covance), rabbit antiCHD3/4 (1:500; Santa Cruz; sc-11378), and mouse IgM anti- $\beta$-actin (1:1000; Cell Signaling Technology). Secondary antibodies used were anti-rabbit Alexa 488 and anti-goat Alexa 568 (1:1000; Invitrogen).

BrdU cell quantification. Mice were injected with $\mathrm{BrdU}(50 \mathrm{mg} / \mathrm{kg}$ body weight) intraperitoneally and killed $1 \mathrm{~h}$ later. Nerves and skin were collected and processed for BrdU immunostaining. After counterstaining with bisbenzimide (Hoechst 33342; Sigma-Aldrich), BrdU positive cells and total nuclei were quantified by counting 10 random fields at $60 \times$ magnification. Processed nerves from three mice of each genotype were included in the quantification ( $\sim 4000$ nuclei for each genotype).

Electron microscopy. Sciatic nerves were immersion fixed in a solution of $2.5 \%$ glutaraldehyde, $2.0 \%$ paraformaldehyde in $0.1 \mathrm{~m}$ sodium phosphate buffer, $\mathrm{pH} 7.4$, overnight at $4^{\circ} \mathrm{C}$. The tissue was then postfixed in $1 \%$ osmium tetroxide in the same buffer for $2 \mathrm{~h}$ at room temperature. Following $\mathrm{OsO}_{4}$ postfixation, the samples were dehydrated in a graded ethanol series, and then further dehydrated in propylene oxide and embedded in Epon or Durcupan epoxy resin. Ultrathin sections were contrasted with Reynolds lead citrate and 8\% uranyl acetate in 50\% EtOH and observed with a Philips CM120 electron microscope and captured with a MegaView III side-mounted digital camera. The $g$ ratio was calculated by division of the axonal diameter by total fiber diameter. Measurements of $g$ ratio were performed using the NIS-Elements D3.10 software (Nikon) for sciatic nerve electron micrographs from three mice of each genotype $(\sim 300$ axons with a diameter of at least $1 \mu \mathrm{m})$. Statistical significance was evaluated using the Student's $t$ test.

Chromatin immunoprecipitation and chromatin immunoprecipitationchip assays. In vivo chromatin immunoprecipitation (ChIP) assays were performed as previously described (Jang et al., 2006), and all data are representative of at least two independent experiments. Antibodies used in this study are as follows; rabbit anti-Egr2/Krox20 (Covance; PRB236P), rabbit anti-Nab2 (Santa Cruz; sc-22815), rabbit anti-CHD3/4 (Santa Cruz; sc-11378), rabbit anti-Chd4 (kind gift from Paul Wade, Research Triangle Park, NC), goat anti-Mta2 (Santa Cruz; sc-9447), or control antibodies normal rabbit IgG (Millipore; 12-370) and normal goat IgG (Santa Cruz; sc-2028). Quantitative PCR was performed on the ChIP samples in duplicate to calculate the percentage recovery of a given segment relative to the total input, using the comparative $C t$ method (Livak, 2001). Primers used for analysis are included in Table 2. To combine ChIP with microarray analysis, amplicons were first generated from ChIP products by whole-genome amplification (SigmaAldrich). Labeling of the samples with Cy5 (experimental, anti-Egr2, anti-Nab2, anti-Chd4, or anti-Mta2) or Cy3 (control, 10\% input) 
Table 2. List of rat primers used in ChIP assays

\begin{tabular}{lllll}
\hline Gene & Region & Forward & Reverse & Location \\
\hline Mpz & $-0.24 /-0.19$ & CTA GGG CTC TCA GGC AAG GA & CCA AAA GGC TAC AGC AAA GGA \\
CX32 & $+5.87 /+5.93$ & GCT GGG ACA CAA GTG CTC TGT & CAG ATC AAA CGCCCT GAC TTC \\
Sqle & $-0.93 /-0.99$ & CAG CGG CCG GGT TAA GT & GGC TAG CTC TGG AGG AGT TCC & Promoter \\
Jun & $-1.12 /-1.19$ & CTGGGAAACAAGCCTTGAGA & ACCAGGGACTCCTGCTTAAGC \\
Ndrg1 & $+37.1 /+37.2$ & CAG ATC GTG CAC TGA CTG GTA GAT & TCC ATT TCT TCT CCC ACC CAT & Upstream \\
\hline
\end{tabular}

A

B

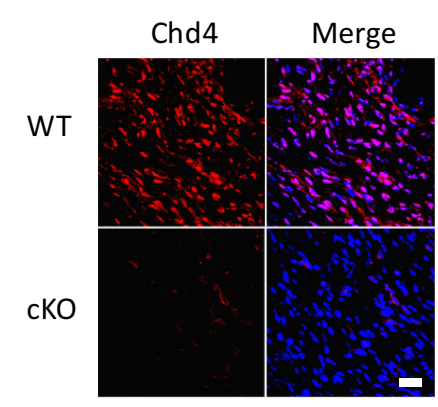

C

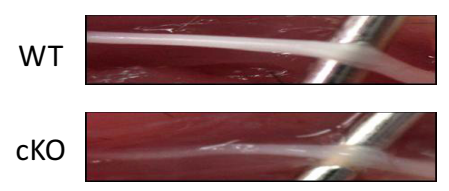

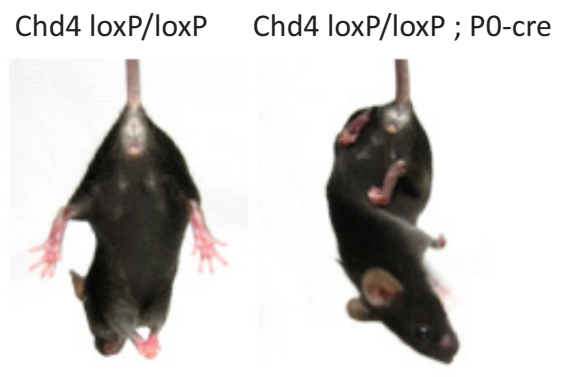

D

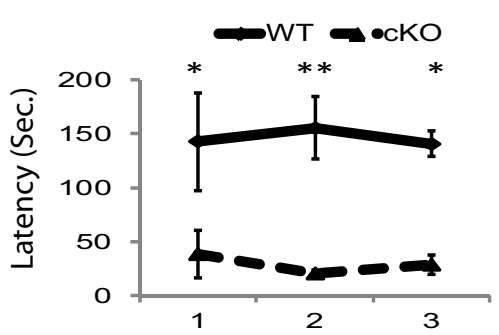

Figure 1. Deficiencies in motor coordination and hindlimb reflex in Chd4 mutant mice. $\boldsymbol{A}$, Immunohistochemistry of Chd4 (red) in the sciatic nerves of control and conditional knock-out mice at P8. Cell nuclei were counterstained with Hoechst (blue). Scale bar, $30 \mu \mathrm{m}$. B, Normal hindlimb postural reflex in a wild-type mouse (Chd4 f/f) characterized by spreading of the limbs. Abnormal reflex in Chd4 mutant mouse where hindlimbs are crossed and withdrawn (P55). C, Gross examination of sciatic nerve dissected from Chd4 K0 and control mice at P30. D, RotaRod performance measuring latency to fall for 4-week-old mice. Three trials per session were measured with 20 min interval between trials. Statistical significance was determined using Student's $t$ test: ${ }^{*} p<$ $0.01 ;{ }^{* *} p<0.001$. Error bars indicate SD.

followed by microarray hybridization was performed as described previously (Jang and Svaren, 2009; Jang et al., 2010) by NimbleGen, using a custom microarray designed with isothermic probes tiled over gene loci identified in the Egr $2^{\text {lo/lo }}$ mouse (Le et al., 2005a). Coordinates of tiled regions are derived from the Rn4 genome build. Gaps in the tiling represent repetitive DNA regions for which unique probes could not be designed. The enrichment ratio of $\mathrm{Cy} 5$ to $\mathrm{Cy} 3$ was plotted on a $\log _{2}$ scale, and displayed as a moving average using a window size of five probes. Peak finding was performed using the NimbleScan software, with a false discovery rate (FDR) of 0.05. All raw data sets for the custom tiled array are available from the NCBI Gene Expression Omnibus website: accession numbers GSE30890 and GSE23648.

\section{Results}

Deficiencies in motor coordination and abnormal hindlimb reflex in Schwann cell-specific Chd4 knock-out mice

To determine the role of the NuRD complex in PNS development, we created a conditional knock-out for Chd4 in Schwann cells by crossing Chd4 ${ }^{\text {loxP/loxP }}$ mice to a line expressing cre recombinase driven by regulatory elements from the Mpz/P0 gene (Feltri et al., 1999, 2002). The excised $C h d 4^{\text {loxP }}$ allele lacks several exons containing the ATPase domain of Chd4 (Williams et al., 2004) and produces an unstable mRNA transcript leading to removal of Chd 4 in cre-expressing cells. Immunohistochemical detection of Chd4 (Fig. $1 \mathrm{~A}$ ) in sciatic nerve shows the majority of the protein is located in the nucleus of wild-type nerve and is absent in mutant nerve.

Heterozygous Chd4 knock-out mice $\left(\mathrm{Chd} 4^{\text {loxP/+}} ; \mathrm{P} 0\right.$-cre) are viable and fertile and have no apparent neuropathy phenotype. Chd 4 mutant mice (Chd $4^{\text {loxP/loxP }}$; $\mathrm{P} 0$-cre) and Chd4 $4^{\text {loxP/loxP }}$ mice lacking cre expression (hereafter designated Chd4 wild-type mice) are overtly indistinguishable from birth through the first 3 weeks of life. At that time, knock-out mice develop an abnormal hindlimb reflex. While wild-type mice spread their hindlimbs when suspended by the tail, Chd 4 mutant mice react by crossing their hindlimbs and drawing them to the body (Fig. $1 B$ ). A similar abnormal hindlimb reflex has been observed in several other models of deficient myelination in the peripheral nervous system (Giese et al., 1992; Gillespie et al., 2000; He et al., 2010). Gross examination of sciatic nerve at 4 weeks revealed the typical white opaque appearance of control nerves and much thinner and translucent appearance of Chd $4 \mathrm{mu}$ tant nerves, a phenotype indicative of hypomyelination (Fig. 1C).

To determine whether mutant mice differ in motor coordination, accelerating Rotarod performance was measured at 4 weeks of age. Rotarod performance was determined by placing mice on a rod rotating at $4 \mathrm{rpm}$. The rotation rate was then increased at $0.12 \mathrm{rpm} / \mathrm{s}$ to calculate the latency time until the mice fell off the rod. Rotarod training consisted of one training session and then three trials. A comparison of mean latency time between Chd4 mutant $(30 \pm 9 \mathrm{~s})$ and wild-type mice (146 $\pm 8 \mathrm{~s})$ shows that Chd4 ablation significantly affects motor coordination (Fig. $1 D)$ before noticeable locomotion difficulties $(p<0.005)$. At 4 months, mice exhibit hindlimb muscle atrophy, wide-based gait, and difficulties in hindlimb coordination, and at 7 months the defects lead to dragging of posterior limbs. Together, these observations show absence of Chd 4 function leads to progressive impairment of motor function.

\section{Schwann cell developmental delay and radial sorting defects} in Chd4 mutant sciatic nerve

To further characterize the myelination process in Chd4 knockout mice, we performed electron microscopy analysis of sciatic nerve at postnatal day 8,15 , and 30 . Peripheral myelination begins shortly after birth and is completed between the second and fourth week of life in mice (Friede and Samorajski, 1968; Ayers and Anderson, 1975) (for review, see Garbay et al., 2000). Compared with wild type, the nerve fibers of Chd4 mutant animals at 

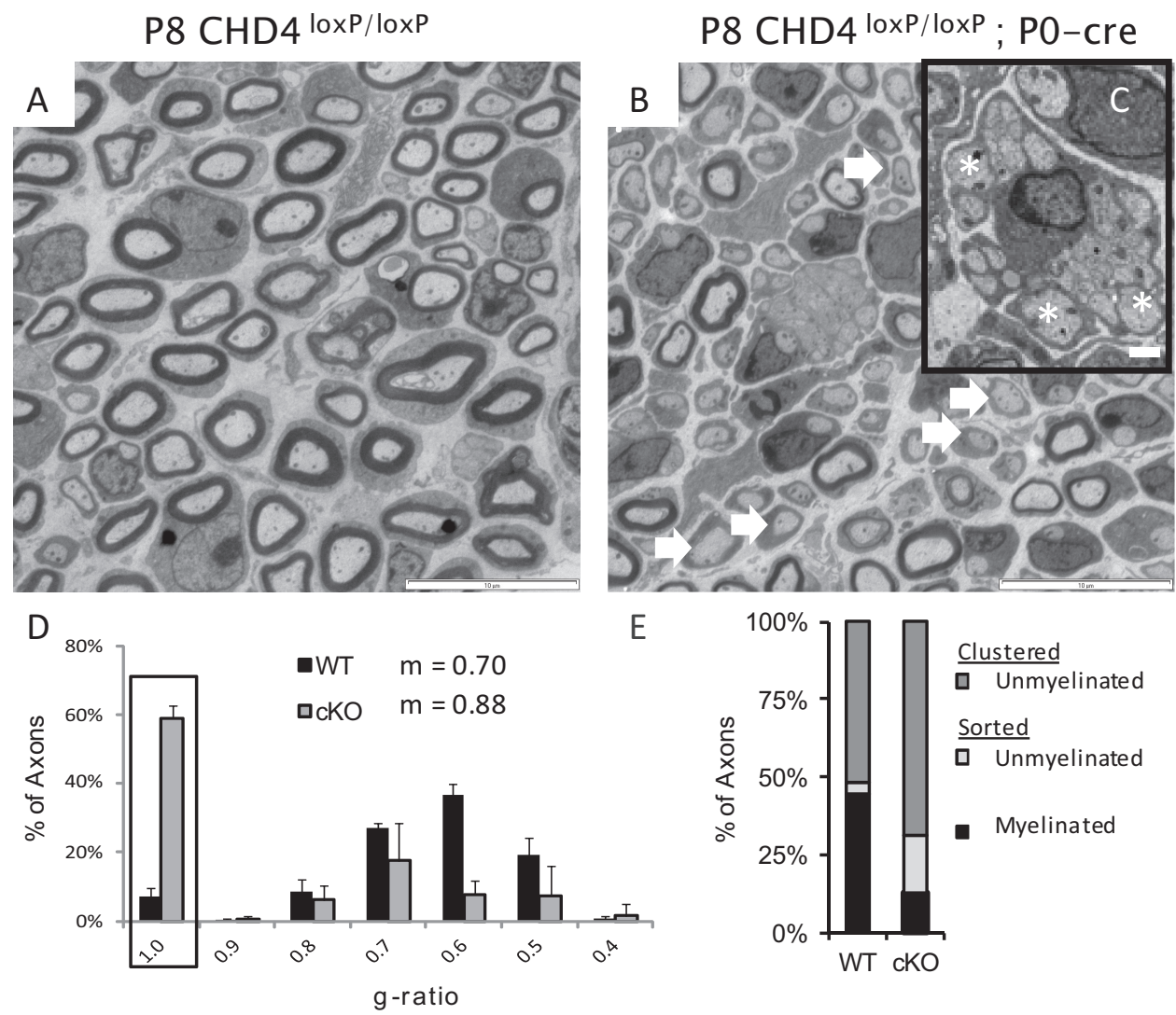

P1 5 CHD4 loxP/loxP

P1 5 CHD4 loxP/loxP ; P0-cre
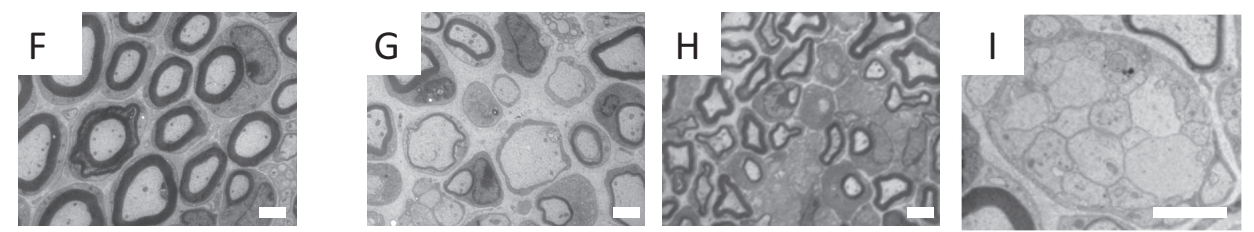

Figure 2. Chd4 mutant mice show a developmental delay. $A, B$, Electron microscopy analysis of sciatic nerve from wild-type and Chd4 mutant mice at P8, showing hypomyelination (arrows) and a radial sorting defect where large-caliber axons are still associated with Remak bundle axons ( $\boldsymbol{C}$, inset) (asterisks). Scale bars: 10 and $1 \mu \mathrm{m}$. $\boldsymbol{D}$, The $g$ ratio measures the ratio of axon diameter to its myelinated diameter. Unmyelinated Schwann cells are represented with a $g$ ratio of 1 (box). Histogram error is given as mean SD for each bin. $\boldsymbol{E}$, Axon classification into categories at P8: clustered-unmyelinated (dark gray), sorted-unmyelinated (light gray), or sorted-myelinated (black). P15 WT sciatic nerve $(\boldsymbol{F})$ contrasts with hypomyelination $(\boldsymbol{G}, \boldsymbol{H})$ and radial sorting defects $(\boldsymbol{I})$ in Chd4 mutant nerve. Scale bar, $2 \mu \mathrm{m}$.

P8 have a striking lack of myelinated axons (Fig. $2 A, B$ ). Moreover, the sparsely distributed axons with a myelin profile are hypomyelinated. By this stage in development, radial sorting of large-caliber axons $(>1 \mu \mathrm{m})$ is complete in wild-type nerve. In contrast, examination of Remak bundles in mutant nerve reveals a significant number of large caliber axons that have not yet established a 1:1 relationship with individual Schwann cells (Fig. $2 C$, inset).

To quantify myelin thickness, the $g$ ratio was analyzed in P8 animals (Fig. $2 D$ ). The $g$ ratio is measured by dividing the axon diameter by its myelinated diameter. The largest $g$ ratio bin for a myelinated axon in wild-type animals peaked at 0.60 while mutant animals peaked at 0.70 , a shift indicating hypomyelination of myelinated axons. In addition, axons completely lacking a myelin sheath ( $g$ ratio of 1 ) form the largest bin $(59.0 \%$ ) of axons in the mutant nerve. In contrast, the wild-type nerve has a small number of amyelinated axons (7.2\%). The mean $g$ ratio for wild-type axons is 0.70 compared with 0.88 in mutant mice and establishes a significant difference in myelin sheath thickness $(p<0.0001)$ between genotypes. This analysis confirms Chd4 knock-out mice have both thinner myelin profiles and fewer myelinated fibers.

The radial sorting defect was further characterized by classifying axons into three categories according to Schwann cell association and myelin state: clustered-unmyelinated, sorted-unmyelinated, or sorted-myelinated (Fig. 2E). Small-caliber axons are clustered into Remak bundles by nonmyelinating Schwann cells and are represented by the clustered-unmyelinated group. A radial sorting defect would also result in large-diameter axons appearing in this group. Sorted axons are associated with a single Schwann cell and have diameters $>1 \mu \mathrm{m}$. At P8, the majority of wild-type nerve is composed of clustered-unmyelinated (52.0 $\pm 4.0 \%)$ and sorted-myelinated axons (44.9 $\pm 4.3 \%)$. In contrast, Chd 4 knock-out nerve contains a significantly larger percentage of clustered-unmyelinated axons, $68.9 \pm 3.2 \%$, reflecting a radial sorting defect of large caliber axons, and relatively few myelinated axons (12.9 $\pm 0.9 \%)$. Sorted-unmyelinated axons also make up a significant percentage of axon classifications in the mutant nerve $(18.19 \pm 3.4 \%)$. 
P30 CHD4 loxP/loxP

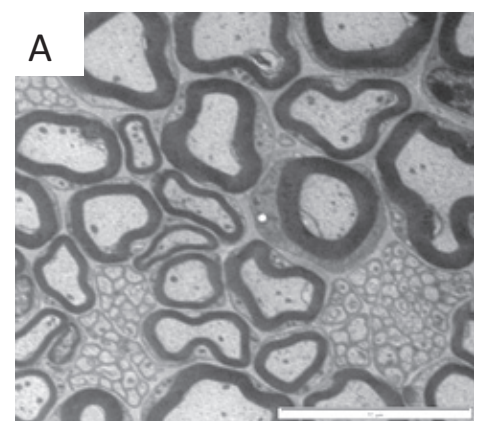

D
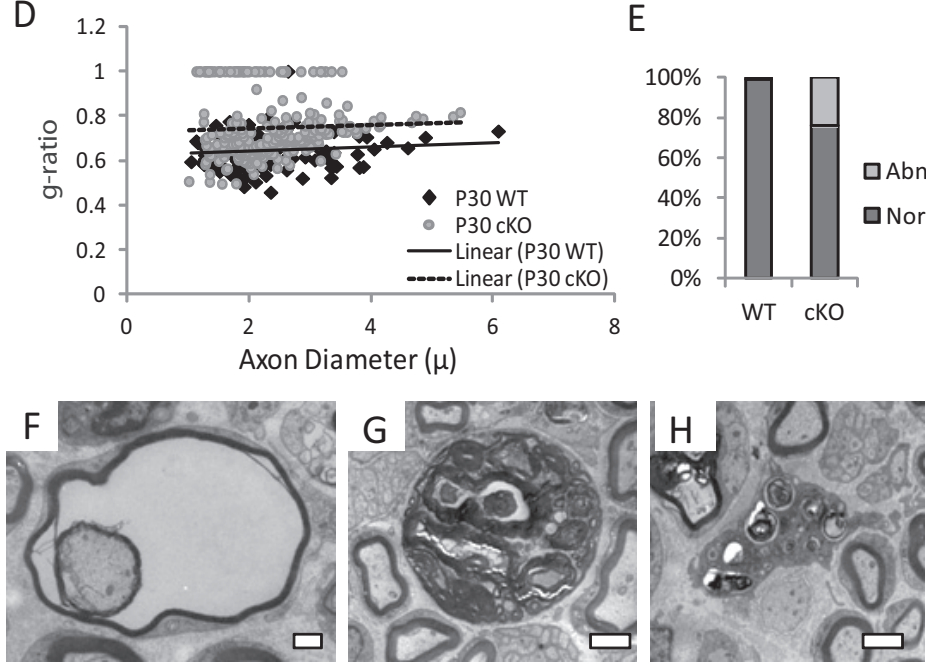

Figure 3. Ablation of Chd4 impairs the ability of Schwann cells to myelinate. Electron micrographs of sciatic nerve from contro $(\boldsymbol{A})$ and $C$ hd 4 cko $(\boldsymbol{B})$ mice at P30. Magnification of myelin wraps show normal periodicity ( $\boldsymbol{C}$, inset). Scale bar, $0.1 \mu \mathrm{m}$. Scatter plot analysis of $g$ ratio and axon diameter $(\boldsymbol{D})$ shows the axon diameter is similar between genotypes; however, thinner myelin wraps axons of all diameters in Chd4 K0 mice. Quantitation of the rate of dysmyelination indicates $24 \%$ of large-caliber axons contain abnormalities in myelination $(\boldsymbol{E})$. Examples include amyelination, frayed myelin $(\boldsymbol{F})$, or disorganized Schwann cell structures containing myelin debris (G). Scale bar: 1 and $2 \mu \mathrm{m}$, respectively. In addition, macrophage infiltration is characteristic of P30 nerve (H). Scale bar, $2 \mu \mathrm{m}$.

At P15, a peak stage of myelination, Chd4-deficient nerve exhibited similar developmental delays found at P8; however, the severity of the phenotype showed greater variability in radial sorting penetrance. Figure 2, $G$ and $H$, highlights the persistence of amyelinated and hypomyelinated axons. Radial sorting defects are also seen at this developmental stage (Fig. $2 I$ ) and $g$ ratio analysis (data not shown) continues to show myelin is significantly thinner than control nerve. Average axon diameters are decreased somewhat (wild type, $2.2 \pm 0.7$ $\mu \mathrm{m}$, vs Chd4 mutant, $1.8 \pm 0.6 \mu \mathrm{m} ; p<0.0001)$. Together, these results indicate Chd 4 is required for the process of axonal sorting in developing Schwann cells. In addition, the lack of a myelin sheath or thin myelin membranes in mutant Schwann cells that have established a 1:1 relationship with an axon may indicate Chd4 requirement for the timely initiation of myelination.

\section{Deletion of Chd4 results in progressive defects in peripheral} nerve myelin formation

Our characterization of the myelination time course in Chd4 knock-out mice was extended to P30, a late myelination/maintenance stage (Fig. 3). As noted above, Chd4 knock-out mice exhibit clear motor deficits beginning at 3 weeks of age. Our analysis at this time point indicates Chd4 knockout mice have completed radial sorting as large-caliber axons are no longer associated with Remak bundles (Fig. 3B). The myelinated axons appear to have normal periodicity, if fewer wraps (Fig. 3C, inset). At P30, there is no statistical difference in overall axon diameter (wild type, $2.4 \pm$ $0.9 \mu \mathrm{m}$, vs Chd4 mutant, $2.3 \pm 0.8 \mu \mathrm{m}$; $p<0.3747)$. The $g$ ratio plots show the myelin thickness in Chd4 mutant mice is consistently thinner across all axon diameters, while the slope of the trend line indicates the axon diameter is unchanged between control and mutant axons (Fig. $3 D)$. A comparative analysis at these three time points is consistent with a developmentally delayed myelination process in Chd4-deficient nerve.

Examination of the myelinated fibers within P30 mutant nerve detected a number of abnormalities in the peripheral nervous system of Chd4-deficient mice. Classification analysis of large-caliber axons as myelinated or abnormal indicates $24.0 \%$ of mutant cells present an unusual phenotype (Fig. 3E). Abnormalities include lack of a myelin sheath, the appearance of large, distended Schwann cells filled with myelin debris, and the presence of vacuole-filled cells with split or frayed myelin layers (Fig. $3 F, G$ ). In addition, immune system activation becomes apparent at this stage with the infiltration of macrophages (Fig. $3 H$ ). No signs of onion bulbs or nonmyelinating Schwann cell defects are detectable in Chd4 mutant nerve at P30.

In summary, the myelination process in Chd4 knock-out animals is developmentally delayed and characterized by the continued presence of promyelinating cells and hypomyelination. Loss of Chd4 impairs defasciculation of large-caliber axons from Remak bundles through P15, indicating a postnatal role of Chd4 in the timing of these processes. While this phenotype is ameliorated by $\mathrm{P} 30$, the onset of inflammation and myelin degradation at P30 indicates that the ablation of Chd4 is incompatible with the maintenance of a myelin sheath in mutant Schwann cells.

\section{Chd4 ablation leads to increased Schwann cell proliferation and deregulation of genes induced and repressed during development}

Since many Schwann cells in Chd 4 mutant mice fail to produce myelin, we hypothesized other attributes of delayed myelination would also be present. Mature myelinating Schwann cells typically undergo cell cycle arrest, but several gene deletions affecting myelination (including Egr2 and Nab mutants) also result in persistent proliferation (Zorick et al., 1999; Le et al., 2005a,b; Bremer et al., 2010; He et al., 2010). The proliferation status of Schwann cells was determined in P8 sciatic nerve. Mice were intraperitoneally injected with BrdU, and then killed $1 \mathrm{~h}$ later for analysis (Fig. 4). The proliferation rate was calculated from the ratio of BrdU-positive nuclei to total nuclei counterstained with 
bisbenzimide. While $3.9 \%$ of cells in wild-type nerve were BrdU positive, Chd4 knock-out mice had a higher level of proliferation, $5.86 \%(p<0.019)$. In summary, the persistence of cell division indicates that Chd4 function is necessary for complete arrest of Schwann cell proliferation.

Several independent studies have shown Egr2 in conjunction with $\mathrm{Nab}$ expression is critical for peripheral myelination (Le et al., 2005b; Desmazières et al., 2008; Baloh et al., 2009). Thus, knock-out mice with hypomyelination phenotype (e.g., Calcineurin B1, Sox10, YY1, Dicer, Hdac1/2) are commonly associated with a deficient level of Egr2 (Kao et al., 2009; Finzsch et al., 2010; He et al., 2010; Pereira et al., 2010; Yun et al., 2010; Chen et al., 2011; Jacob et al., 2011). However, in Chd4-deficient mice, Egr2/Krox20, and Nab2 maintain wild-type or greater mRNA expression levels throughout development (Fig. 5A). This is also true of protein expression for Egr2 (Fig. $5 B$ ). Importantly, the Chd 4 mutant phenotype does not stem from reduced Egr2/Nab expression, suggesting that Chd 4 is required for a step that is downstream of Egr2 induction itself.

Many of the genes typically expressed in immature or promyelinating Schwann cells remain elevated in peripheral nerve of Egr2- and Nab-deficient mice (Le et al., 2005a,b). Since Chd4 was found to mediate repression by Nab proteins (Srinivasan et al., 2006), we investigated whether such genes are similarly de-repressed in Chd4 mutant mice. During development, the timing of myelination is sensitive to transient Oct6/ Pou3f1 expression at the promyelinating stage and subsequent repression following the initiation of myelination (Scherer et al., 1994; Bermingham et al., 1996; Blanchard et al., 1996; Jaegle et al., 1996). In Chd4 mutant nerve, expression of Oct6/Pou3f1 is significantly upregulated at both P8 (1.9-fold) and P30 (5.2-fold) (Fig. $5 A, C$ ). Several studies have identified other Schwann cell markers that are expressed during the immature stage of Schwann cell development and then are downregulated as development progresses. These genes include Sox2 (Le et al., 2005a,b), L1cam, Id2, the p75/nerve growth factor receptor (Jessen et al., 1990), the Egr family member, Egr1 (Topilko et al., 1997), Notch1 (Woodhoo et al., 2009), and c-Jun (Parkinson et al., 2004) (for review, see Jessen and Mirsky, 2008). Interestingly, these genes exhibit wild-type expression levels during the initiation of myelination at P8 (Fig. 5D). However, expression of these markers is significantly upregulated in Chd4 mutant mice at the P30 time point. De-repression of genes characteristic of immature Schwann cells late in developing nerve indicates Chd4 deficiency causes failure to maintain gene repression patterns typical of mature peripheral nerve.

Egr2 is required for developmental induction of lipid biosynthesis and major myelin genes (Topilko et al., 1994; Le et al., 2005a). We examined the expression levels of Mpz, the cholesterol biosynthesis

$E$ ${ }^{* *} p<0.01 ;{ }^{* * *} p<0.005$.

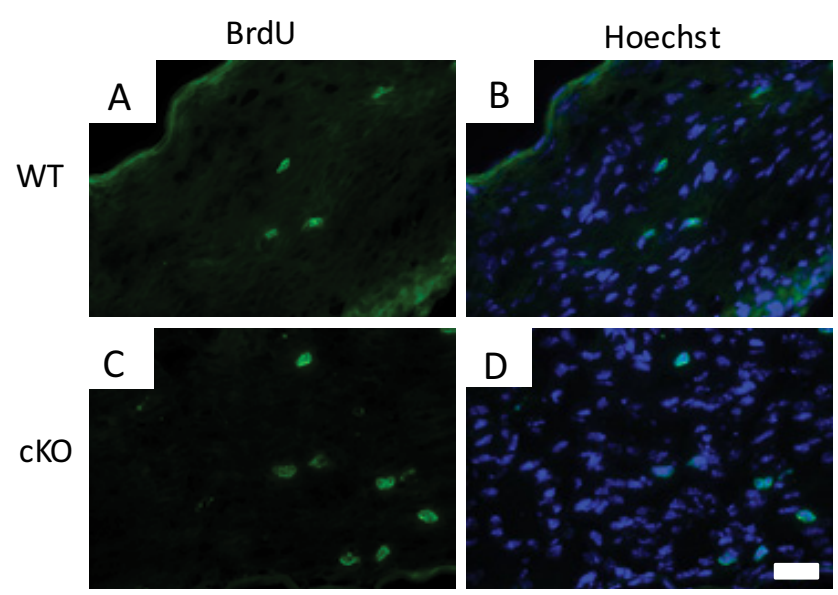

Figure 4. Persistence of Schwann cell proliferation. $\boldsymbol{A}-\boldsymbol{D}$, BrdU immunohistochemical analysis of $\mathrm{P} 8 \mathrm{Chd} 4$ cko sciatic nerve demonstrates an increased number of proliferating cells compared with control littermates. The BrdU-positive nuclei were counted, and proliferation was determined as a percentage of BrdU-positive nuclei compared with all Hoechst-stained nuclei in the nerve section. Scale bar, $30 \mu \mathrm{m} . p<0.019 ; n=3$ for each genotype.
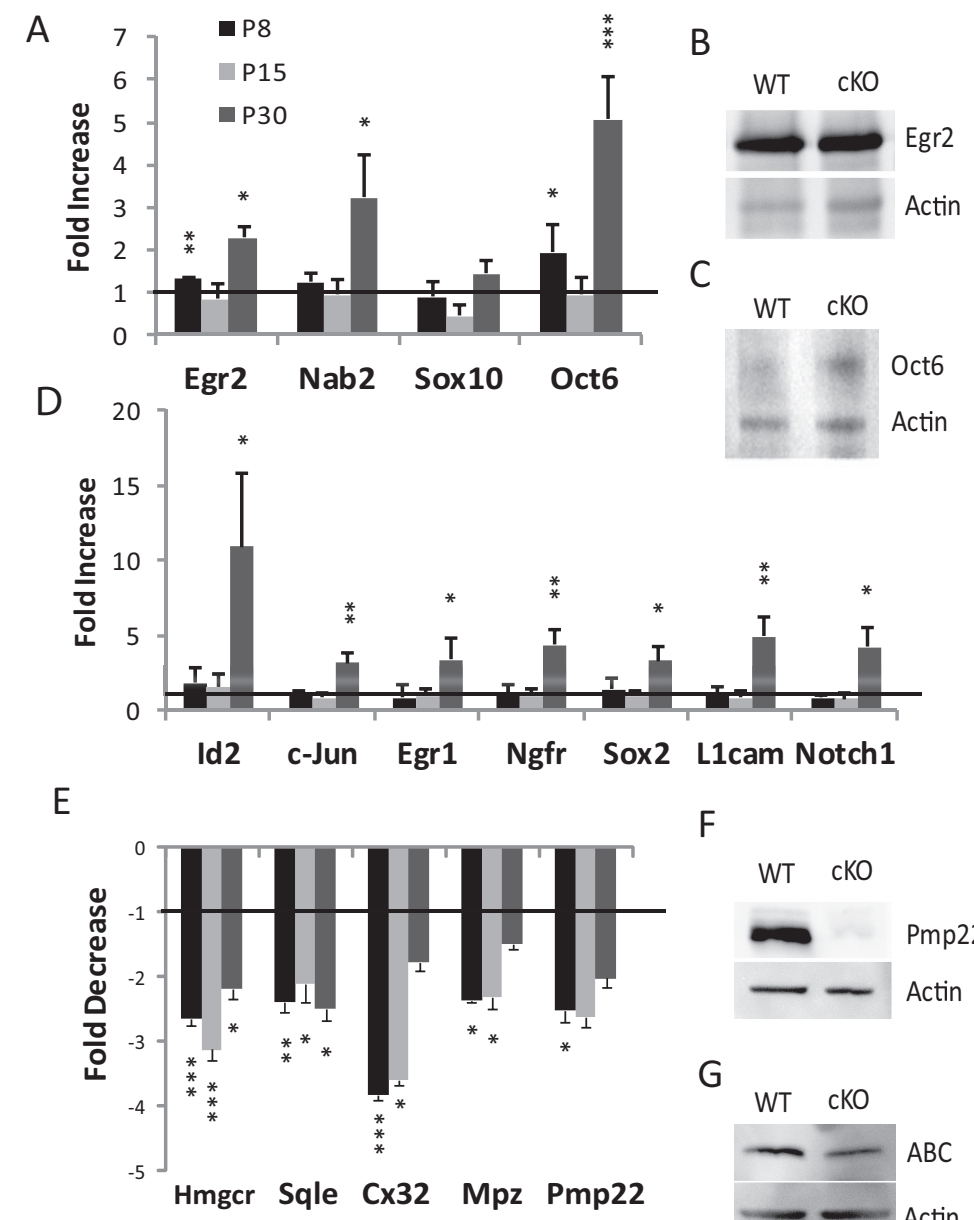

$\mathrm{F}$

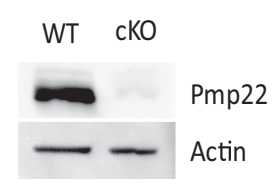

G

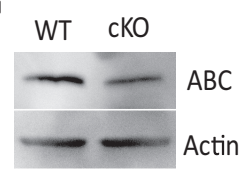

Figure 5. Chd4 deletion results in deregulation of $S$ chwann cell genes induced and repressed during development. $A, B$, The mRNA expression levels for the indicated genes were determined by quantitative RT-PCR from sciatic nerve samples at the $P 8, P 15$, and $P 30$ time points. Expression data are presented as a ratio of Chd4 mutant compared with wild-type mRNA levels $(\boldsymbol{C})$. P30 protein levels of Egr2 (D), 0ct6 (E), activated $\beta$-catenin $(\boldsymbol{G})$, and P4 levels of Pmp22 $(\boldsymbol{F})$ mirror the levels found in the mRNA expression data. Error bars indicate SD. Line represents relative level in wild-type mice. ${ }^{*} p<0.05$; 
genes, HMG CoA-reductase $(\mathrm{Hmgcr})$, and squalene epoxidase (Sqle), Connexin 32 (Cx32), and Pmp22 in mutant animals by quantitative RT-PCR, and found that they were strongly downregulated relative to wild type (Fig. $5 E$ ) at multiple developmental time points. Furthermore, protein levels of Pmp22 are greatly reduced in the Chd4 knock-out at $\mathrm{P} 4$ (Fig. $5 F$ ). Myelin genes Pmp22 and Mpz are cooperatively activated by Egr2 and Sox10 (LeBlanc et al., 2007; Jang et al., 2010; Jones et al., 2011). However, quantitative RT-PCR analysis of Sox10 [and Oct6 and Egr2, which are regulated by Sox10 (Finzsch et al., 2010)] indicate that Sox10 levels are not reduced in Chd4 mutant mice.

NuRD components, Hdac1 and Hdac2, have previously been shown to regulate oligodendrocyte differentiation by disrupting the $\beta$-catenin-TCF interaction (Ye et al., 2009). Hdacmediated control of activated $\beta$-catenin $(\mathrm{ABC})$ is also critical in peripheral myelination (Jacob et al., 2011). However, analysis of Chd4 mutant nerve for elevated protein levels of $\mathrm{ABC}$ indicates this pathway is unchanged between genotypes (Fig. $5 G$ ).

\section{The NuRD complex assembles on dynamically regulated genes in myelinating Schwann cells}

Initial studies of the NuRD complex suggested that it was predominantly repressive, and studies of Chd4 binding supported its role in developmentally regulated gene repression through recruitment to chromatin by Egr2/Nab protein complexes (Srinivasan et al., 2006; Mager et al., 2008). However, studies of Chd4 function in other systems have shown that it can also be involved in gene activation (Williams et al., 2004; Yoshida et al., 2008; Miccio et al., 2010). Given that Egr2 and $\mathrm{Nab}$ knock-outs exhibit both reduced expression of myelin genes and de-repressed levels of immature Schwann cell genes (Le et al., 2005a,b), it was possible that Chd4 had a similar bimodal effect on transcription in peripheral nerve. Therefore, we examined the role of Chd4 in gene activation or repression by testing for Chd4 occupancy of developmentally regulated genes using in vivo ChIP. Immunoprecipitations were performed using pooled $\mathrm{P} 15$ rat sciatic nerve samples and performed on three independent chromatin preparations with antibodies targeting Egr2, Chd4, and another NuRD component, Mta2 (Fig. 6).

Gene expression is greatly reduced for myelin protein and lipid biosynthesis genes in Egr2, Nab protein, and Chd4deficient nerve. Therefore, we further examined NuRD binding to the promoter regions of $M p z, C x 32$, and Sqle, genes previously described to be positively regulated by Egr2 (Bondurand et al., 2001; Jang and Svaren, 2009; Jang et al., 2010) (Fig. $6 \mathrm{~A}$ ). The most robust binding of NuRD components was observed at the Sqle promoter, where Chd4 and Mta2 binding was observed at 6.6- and 6.5-fold over IgG control, respectively. Occupancy of Egr2 was also confirmed at this site to bind 38.7-fold higher than background. Significant accumulation of Egr2 was also detected in $c$-Jun, a gene repressed during myelination (Fig. 6B). Previous studies have shown Egr2 suppresses the JNK/c-Jun signaling pathway to regulate cell proliferation and death (Parkinson et al., 2004, 2008). ChIP analysis in myelinating sciatic nerve place binding of Egr2 and Mta2 of the NuRD complex $1 \mathrm{~kb}$ upstream of the c-Jun promoter. As a negative control, there was minimal binding of all three factors to a negative site in Ndrg1. These data demonstrate binding of both Egr2 and NuRD components to activated and repressed genes during peripheral nerve myelination.
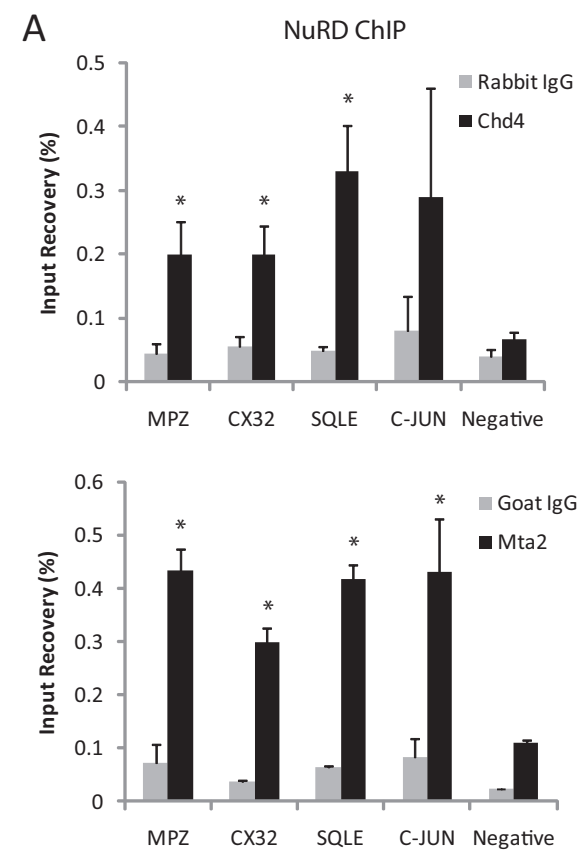

B

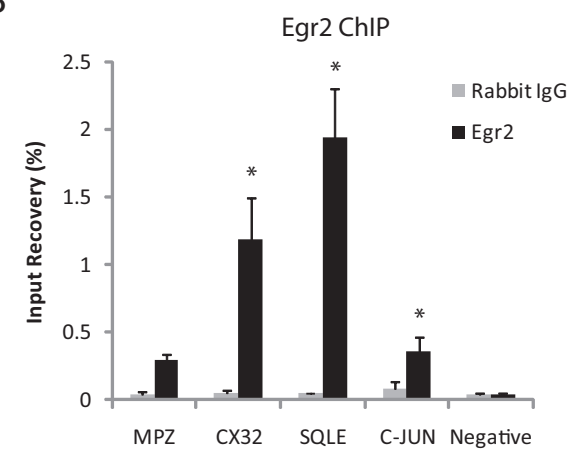

Figure 6. ChIP analysis for occupancy of Egr2, Chd4, and MTA2 on Egr2 activated and repressed genes. The bar graph shows ChIP analysis of NuRD subunits, Chd4 and Mta2 ( $A$ ), and Egr2 $(\boldsymbol{B})$ binding to activated and repressed genes in P15 rat sciatic nerve. Quantitative $P C R$ was used to calculate percentage recovery for both experimental and control $(\mathrm{IgG})$ immunoprecipitations relative to total input, and the mean of three independent ChIP experiments is shown. The negative control site is an Egr2 negative binding site in Ndrg1. Error is shown as \pm SEM. ${ }^{*} p<0.05$.

To examine locus-wide binding of the NuRD complex in coordination with Egr2/Nab proteins, we examined protein binding by ChIP-chip array in myelinating sciatic nerve. The accumulation of the NuRD complex at multiple gene loci was assessed using in vivo ChIP samples hybridized to a custom tiled microarray described previously (Jang et al., 2010). ChIP assays for NuRD binding were performed in P15 rat sciatic nerve using two antibodies for Chd4 and an antibody for another NuRD component, Mta2. Previous ChIP-chip data for Egr2 (Jang et al., 2010) and an additional array for Nab2 were also used in this analysis. This array contains tiled probes for $50-100 \mathrm{~kb}$ regions around genes dynamically regulated during peripheral nerve myelination. Using NimbleScan peak finding software (FDR < 0.05), NuRD binding was found on $46.7 \%$ of Egr2-induced genes, such as myelin and lipid synthesis genes (Fig. 7A). However, binding to Egr2-repressed genes occurred at a rate of $60 \%$ to genes typically expressed in promyelinating Schwann cells such as Oct6, Sox2, or Id2 (Table 3 ) or on the 


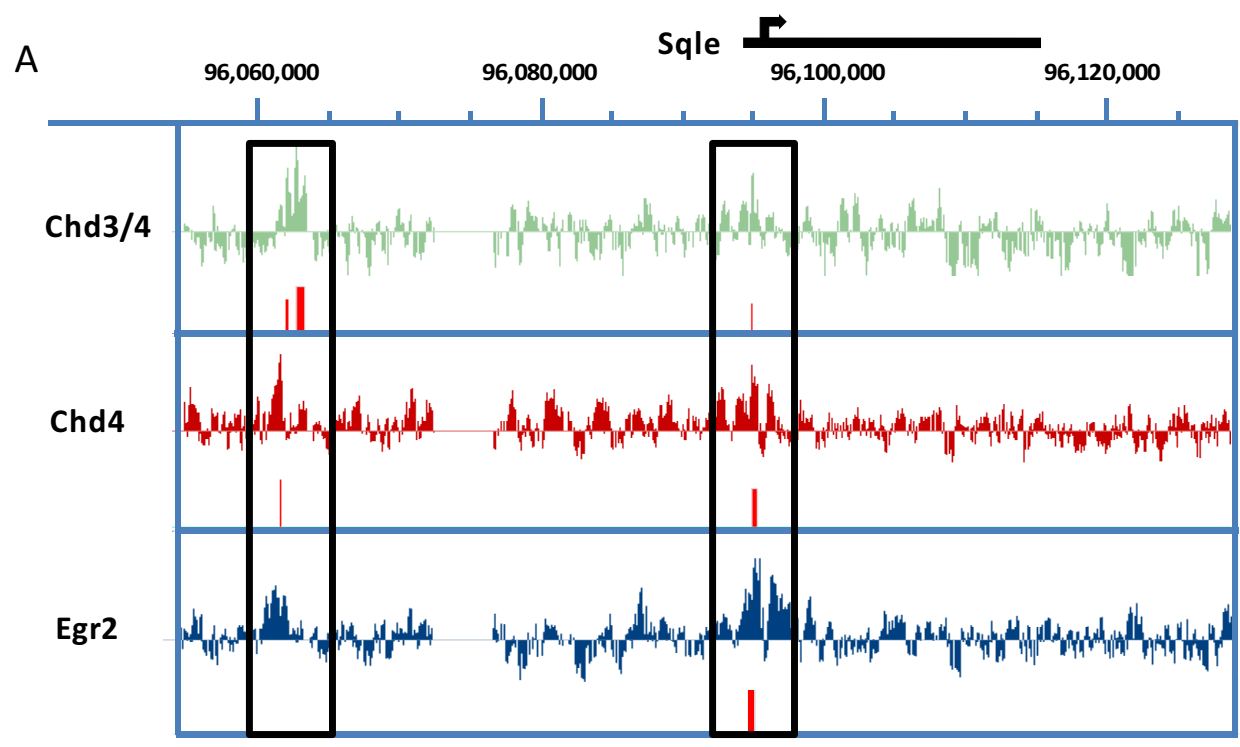

B

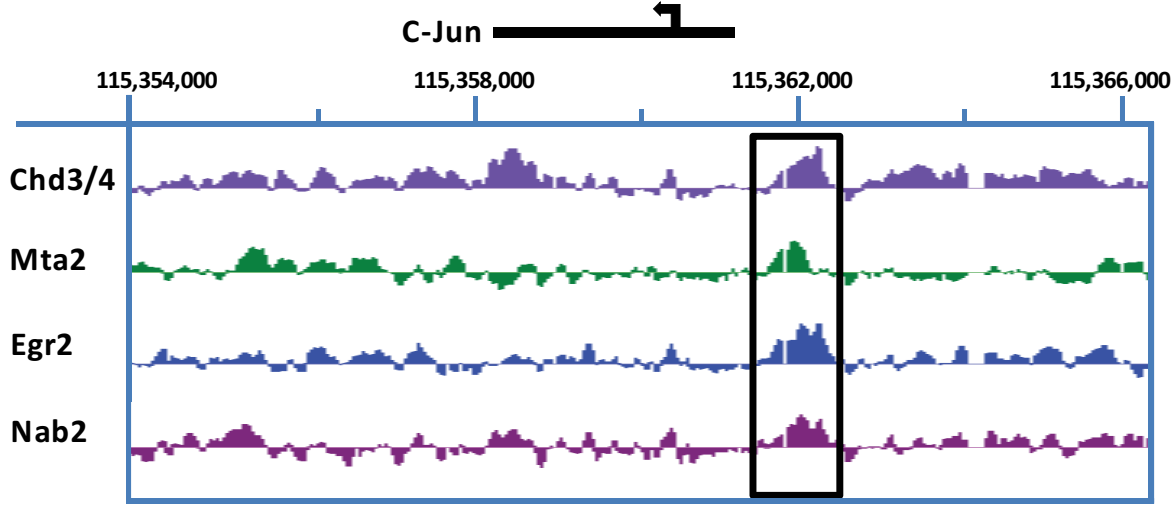

Figure 7. NuRD complex components and Egr2 assemble on both activated and repressed genes during myelination. Chd4 binding is found on Sqle ( $\boldsymbol{A})$, and a negative regulator of myelination, c-Jun (B). ChIP-chip data for Egr2 (Jang et al., 2010) and two independent Chd4 antibodies were used to determine the binding location of Chd4 in P15 rat sciatic nerve. Data were analyzed using NimbleScan peak finding software. Peaks with a value of FDR $<0.05$ are colored in red. ChIP-chip analysis for occupancy of Egr2, Chd4, and MTA2 on the Egr2-repressed gene, $\boldsymbol{c}-$ Jun ( $\boldsymbol{B}$ ), confirms binding of these proteins to the same site upstream of the c-Jun promoter (box).

Table 3. ChIP-chip analysis of NuRD binding

\begin{tabular}{llll}
\hline Category & Chd3/4 ( $\alpha 1)(\%)$ & Chd4 $(\alpha 2)(\%)$ & Both (\%) \\
\hline Myelin genes & 100 & 80.0 & 70.0 \\
Lipid synthesis/transport & 77.8 & 83.3 & 33.3 \\
Transcription factors & 100 & 83.3 & 75.0 \\
Egr2-activated genes & 86.7 & 83.3 & 46.7 \\
Egr2-repressed genes & 80.0 & 80.0 & 60.0 \\
\hline
\end{tabular}

Using NimbleScan peak finding software (FDR $<0.05$ ), NuRD binding was determined for two independent antibodies for Chd4. Percentage of genes with Chd4 binding was found for each antibody on genes representing myelin genes, lipid synthesis, or transcription factors. Binding percentage was also determined by whether the gene is induced or repressed in the Egr2-deficient mice. Percentage of peaks found between both Chd4 ChIP-chip data sets was determined to be shared by $46.7 \%$ of Egr2-induced genes, such as myelin and lipid synthesis genes. However, binding to Egr2-repressed genes occurred at $60 \%$ of genes typically expressed in immature/promyelinating Schwann cells, such as 0ct6, Sox2, or Id2. Overall, ChIP-chip analysis of NuRD binding reveals Chd4 occupancy at several genes that are either repressed or activated by Egr2 activity.

negative regulator of myelination, c-Jun (Fig. $7 B$ ). Overall, ChIP-chip analysis of NuRD binding reveals that Chd 4 binds to genes that are both activated and repressed by Egr2 activity.

\section{Discussion}

Schwann cells of the peripheral nervous system require coordinated gene expression changes for myelin development to occur in a timely fashion. While epigenetic mechanisms play a significant role in a variety of developmental processes, distinct chromatin remodeling pathways that modulate gene expression changes during peripheral myelination have only recently begun to be investigated. Previous studies uncovered a novel mechanism for NAB repression of Egr2 target genes through interaction with the Chd4 subunit of the NuRD complex (Srinivasan et al., 2006; Mager et al., 2008). Our results now demonstrate that Chd 4 ablation in the peripheral nervous system results in impaired Schwann cell differentiation leading to a developmental delay in myelination, reflected in the prevalence of promyelinating Schwann cells, hypomyelination, and enhanced proliferation at P8. Inefficient initiation of the myelinproducing stage in Schwann cell development indicates loss of Chd4 results in delayed and incomplete Schwann cell differentiation. The myelination status deteriorates considerably by P30, resulting in significant ataxia, myelin degeneration, and altered gene expression patterns, indicating that Chd4 may also play a role during later stages of Schwann cell myelination for the maturation and homeostasis of the myelin sheath beyond P15.

Although the association of Chd 4 with NAB coregulators provided the mechanistic basis for this study, the resulting phenotype is significantly less severe than that caused by deletion of both NAB genes, or by knock-in of a NAB-resistant allele of Egr2 (Le et al., 2005b; Desmazières et al., 2008; Baloh 
et al., 2009). One possible explanation could be redundancy with Chd3. Chd4 is highly similar to Chd3, and both proteins have been shown to be part of the NuRD complex (Ramírez and Hagman, 2009; Y. Wang et al., 2009) and have been shown to interact with Nab2 (Srinivasan et al., 2006). However, using an antibody that detects both Chd3 and Chd4, there seems to be little background expression of Chd3 after deletion of Chd4, although it is possible that residual levels could compensate to some degree. In addition, NAB proteins have two independent repression domains, one of which exerts its activity in an Hdac- and Chd4-independent manner (Srinivasan et al., 2006). Therefore, it is anticipated that NAB proteins retain some level of repressive activity in the absence of NuRD activity.

Our studies of Chd4-deficient nerve revealed not only derepression of genes that are normally repressed in mature myelinating Schwann cells, but also reduced levels of several critical myelin genes in sciatic nerves from knock-out mice. Accordingly, ChIP analysis in myelinating sciatic nerve detected binding of Chd 4 and another NuRD subunit (Mta2) at promoters of repressed genes, consistent with direct repression of negative regulators by the NuRD complex during development. This analysis also detected binding of Chd4 and MTA2 to promoters that are induced during myelination. Our findings are similar in many respects to analysis of $\mathrm{Nab} 1 / \mathrm{Nab} 2$ double knock-out mice (Le et al., 2005b), which revealed that $\mathrm{Nab}$ proteins are required for both gene activation and gene repression by Egr2.

Other studies of Chd4 function have shown direct requirement of the NuRD complex to both activate and repress transcription in hematopoietic development (Yoshida et al., 2008; Miccio and Blobel, 2010; Miccio et al., 2010). Although we detect binding of NuRD components at both activated and repressed genes, it is possible that $\mathrm{H} 3 \mathrm{~K} 4$ trimethylation at active promoters prevents repressive remodeling by the NuRD complex (Nishioka et al., 2002; Zegerman et al., 2002). In addition, the activation state of a given promoter may reflect a balance between deacetylation by the NuRD complex, and acetylation by other coactivators (CBP/p300), which are recruited by Egr 2 and associated factors. Interestingly, genomic profiling of Hdac binding has revealed widespread binding of Hdac1/2 to active genes (Z. Wang et al., 2009). Therefore, it is possible that histone deacetylation at regulatory regions may precede positive or negative methylation (K4 vs K9/K27) at different genes as myelination proceeds.

Recent studies have shown that peripheral nerve myelination depends upon activity of Hdac1/2 (Chen et al., 2011; Jacob et al., 2011). The role of these histone deacetylases is mechanistically complex since they are constituents of multiple complexes (NuRD, Sin3a, CoRest). In addition, it is clear that they also have important nonhistone substrates. For example, in glial development, $\mathrm{Hdac} 1$ and $\mathrm{Hdac} 2$ regulate oligodendrocyte differentiation by disrupting the $\beta$-catenin-TCF interaction (Ye et al., 2009), and HDAC-mediated deacetylation of NF- $\kappa \mathrm{B}$ is a determinant of gene regulation (Chen et al., 2011). The phenotype of the Chd4deficient peripheral nerve is significantly milder compared with Hdac1/2-deficient mice, which exhibit failure to myelinate and lack of Egr2 expression (Chen et al., 2011; Jacob et al., 2011). We did not observe any obvious level of apoptosis exhibited by Hdacdeficient mice (Jacob et al., 2011), and the level of Oct6 expression indicates that NF- $\kappa \mathrm{B}$ acetylation status is likely not perturbed in Chd4-deficient mice. In addition, Western blotting indicated no significant difference in $\beta$-catenin at P30. This likely reflects the fact that NuRD complexes mediate only a subset of Hdac-regulated events.

Substantial progress has been made in identifying transcription factors that coordinate gene expression during myelination. However, for many such studies, a common feature of the knock-out phenotype is reduced Krox20/Egr2 expression, as observed in the Sox10, Calcineurin B1, Hdac, Oct6, dicer, and YY1 knock-out studies of peripheral nerve (Blanchard et al., 1996; Kao et al., 2009; Finzsch et al., 2010; He et al., 2010; Pereira et al., 2010; Yun et al., 2010; Chen et al., 2011; Jacob et al., 2011). Importantly, the Chd4 knock-out phenotype does not stem from reduced Egr2 expression, suggesting that gene regulation by Chd 4 is required downstream of (or parallel to) Egr2 activity.

While development favors induction of a myelinated nerve state, these conditions must be quickly reversible in response to nerve injury. During nerve injury, Schwann cells undergo a process of dedifferentiation, and suppress myelin genes while inducing negative regulators (Jessen and Mirsky, 2008). For the nervous system to complete a full recovery and remyelinate, the balance of transcriptional control must then swing back to promoting Schwann cell myelination. Ineffective suppression of negative regulators significantly affects both timing and extent of remyelination. The molecular pathways controlling repression of dedifferentiation factors are not well understood. However, recent studies have elucidated the importance of epigenetic regulation of myelin gene expression. Shen et al. (2008) showed remyelination efficiency in oligodendrocytes decreases with age due to the reduced ability of senescent cells to recruit HDAC proteins to the promoters of differentiation inhibitors and neural stem cell markers. Of note, the NuRD complex is one of the major HDAC-containing chromatin-remodeling complexes. Moreover, subunits of the $\mathrm{NuRD}$ complex are prone to silencing during aging leading to changes in chromatin modification, structure, and protein recruitment (Pegoraro and Misteli, 2009). Improving our understanding of the epigenetic mechanisms that control myelin formation and maintenance, including recruitment of chromatin remodeling complexes, will be critical to elucidate the genomic programming required for myelination.

\section{References}

Ayers MM, Anderson R (1975) Development of onion bulb neuropathy in the Trembler mouse. Comparison with normal nerve maturation. Acta Neuropathol 32:43-59.

Baloh RH, Strickland A, Ryu E, Le N, Fahrner T, Yang M, Nagarajan R, Milbrandt J (2009) Congenital hypomyelinating neuropathy with lethal conduction failure in mice carrying the Egr2 I268N mutation. J Neurosci 29:2312-2321.

Bermingham JR Jr, Scherer SS, O’Connell S, Arroyo E, Kalla KA, Powell FL, Rosenfeld MG (1996) Tst-1/Oct-6/SCIP regulates a unique step in peripheral myelination and is required for normal respiration. Genes Dev 10:1751-1762.

Blanchard AD, Sinanan A, Parmantier E, Zwart R, Broos L, Meijer D, Meier C, Jessen KR, Mirsky R (1996) Oct-6 (SCIP/Tst-1) is expressed in Schwann cell precursors, embryonic Schwann cells, and postnatal myelinating Schwann cells: comparison with Oct-1, Krox-20, and Pax-3. J Neurosci Res 46:630-640.

Bondurand N, Girard M, Pingault V, Lemort N, Dubourg O, Goossens M (2001) Human Connexin 32, a gap junction protein altered in the $\mathrm{X}$-linked form of Charcot-Marie-Tooth disease, is directly regulated by the transcription factor SOX10. Hum Mol Genet 10:2783-2795.

Bremer J, O’Connor T, Tiberi C, Rehrauer H, Weis J, Aguzzi A (2010) Ablation of Dicer from murine Schwann cells increases their proliferation while blocking myelination. PLoS One 5:e12450.

Chen Y, Wang H, Yoon SO, Xu X, Hottiger MO, Svaren J, Nave KA, Kim HA, 
Olson EN, Lu QR (2011) HDAC-mediated deacetylation of NF- $\kappa \mathrm{B}$ is critical for Schwann cell myelination. Nat Neurosci 14:437-441.

Decker L, Desmarquet-Trin-Dinh C, Taillebourg E, Ghislain J, Vallat JM, Charnay P (2006) Peripheral myelin maintenance is a dynamic process requiring constant Krox20 expression. J Neurosci 26:9771-9779.

Denslow SA, Wade PA (2007) The human Mi-2/NuRD complex and gene regulation. Oncogene 26:5433-5438.

Desmazières A, Decker L, Vallat JM, Charnay P, Gilardi-Hebenstreit P (2008) Disruption of Krox20-Nab interaction in the mouse leads to peripheral neuropathy with biphasic evolution. J Neurosci 28:5891-5900.

Feltri ML, D’Antonio M, Previtali S, Fasolini M, Messing A, Wrabetz L (1999) P0-Cre transgenic mice for inactivation of adhesion molecules in Schwann cells. Ann N Y Acad Sci 883:116-123.

Feltri ML, Graus Porta D, Previtali SC, Nodari A, Migliavacca B, Cassetti A, Littlewood-Evans A, Reichardt LF, Messing A, Quattrini A, Mueller U, Wrabetz L (2002) Conditional disruption of beta 1 integrin in Schwann cells impedes interactions with axons. J Cell Biol 156:199-209.

Finzsch M, Schreiner S, Kichko T, Reeh P, Tamm ER, Bösl MR, Meijer D, Wegner M (2010) Sox10 is required for Schwann cell identity and progression beyond the immature Schwann cell stage. J Cell Biol 189:701-712.

Friede RL, Samorajski T (1968) Myelin formation in the sciatic nerve of the rat. A quantitative electron microscopic, histochemical and radioautographic study. J Neuropathol Exp Neurol 27:546-570.

Garbay B, Heape AM, Sargueil F, Cassagne C (2000) Myelin synthesis in the peripheral nervous system. Prog Neurobiol 61:267-304.

Giese KP, Martini R, Lemke G, Soriano P, Schachner M (1992) Mouse P0 gene disruption leads to hypomyelination, abnormal expression of recognition molecules, and degeneration of myelin and axons. Cell 71:565-576.

Gillespie CS, Sherman DL, Fleetwood-Walker SM, Cottrell DF, Tait S, Garry EM, Wallace VC, Ure J, Griffiths IR, Smith A, Brophy PJ (2000) Peripheral demyelination and neuropathic pain behavior in periaxin-deficient mice. Neuron 26:523-531.

He Y, Kim JY, Dupree J, Tewari A, Melendez-Vasquez C, Svaren J, Casaccia P (2010) Yyl as a molecular link between neuregulin and transcriptional modulation of peripheral myelination. Nat Neurosci 13:1472-1480.

Jacob C, Christen CN, Pereira JA, Somandin C, Baggiolini A, Lötscher P, Ozçelik M, Tricaud N, Meijer D, Yamaguchi T, Matthias P, Suter U (2011) HDAC1 and HDAC2 control the transcriptional program of myelination and the survival of Schwann cells. Nat Neurosci 14:429-436.

Jaegle M, Mandemakers W, Broos L, Zwart R, Karis A, Visser P, Grosveld F, Meijer D (1996) The POU factor Oct-6 and Schwann cell differentiation. Science 273:507-510.

Jang SW, Svaren J (2009) Induction of myelin protein zero by early growth response 2 through upstream and intragenic elements. J Biol Chem 284:20111-20120.

Jang SW, LeBlanc SE, Roopra A, Wrabetz L, Svaren J (2006) In vivo detection of Egr2 binding to target genes during peripheral nerve myelination. J Neurochem 98:1678-1687.

Jang SW, Srinivasan R, Jones EA, Sun G, Keles S, Krueger C, Chang LW, Nagarajan R, Svaren J (2010) Locus-wide identification of Egr2/Krox20 regulatory targets in myelin genes. J Neurochem 115:1409-1420.

Jessen KR, Mirsky R (2008) Negative regulation of myelination: relevance for development, injury, and demyelinating disease. Glia 56:1552-1565.

Jones EA, Lopez-Anido C, Srinivasan R, Krueger C, Chang LW, Nagarajan R, Svaren J (2011) Regulation of the PMP22 gene through an intronic enhancer. J Neurosci 31:4242-4250.

Kao SC, Wu H, Xie J, Chang CP, Ranish JA, Graef IA, Crabtree GR (2009) Calcineurin/NFAT signaling is required for neuregulin-regulated Schwann cell differentiation. Science 323:651-654.

Le N, Nagarajan R, Wang JY, Araki T, Schmidt RE, Milbrandt J (2005a) Analysis of congenital hypomyelinating Egr2Lo/Lo nerves identifies Sox2 as an inhibitor of Schwann cell differentiation and myelination. Proc Natl Acad Sci U S A 102:2596-2601.

Le N, Nagarajan R, Wang JY, Svaren J, LaPash C, Araki T, Schmidt RE, Milbrandt J (2005b) Nab proteins are essential for peripheral nervous system myelination. Nat Neurosci 8:932-940.

LeBlanc SE, Ward RM, Svaren J (2007) Neuropathy-associated Egr2 mutants disrupt cooperative activation of myelin protein zero by Egr2 and Sox10. Mol Cell Biol 27:3521-3529.

Lee SL, Wang Y, Milbrandt J (1996) Unimpaired macrophage differentiation and activation in mice lacking the zinc finger transplantation factor NGFI-A (EGR1). Mol Cell Biol 16:4566-4572.
Liu J, Casaccia P (2010) Epigenetic regulation of oligodendrocyte identity. Trends Neurosci 33:193-201.

Livak KJ, Schmittgen TD (2001) Analysis of relative gene expression data using real-time quantitative PCR and the $2^{-\Delta \Delta C(\mathrm{~T})}$ method. Methods 25:402-408.

Mager GM, Ward RM, Srinivasan R, Jang SW, Wrabetz L, Svaren J (2008) Active gene repression by the EGR2/NAB complex during peripheral nerve myelination. J Biol Chem 283:18187-18197.

Marfella CG, Imbalzano AN (2007) The Chd family of chromatin remodelers. Mutat Res 618:30-40.

Marin-Husstege M, Muggironi M, Liu A, Casaccia-Bonnefil P (2002) Histone deacetylase activity is necessary for oligodendrocyte lineage progression. J Neurosci 22:10333-10345.

Miccio A, Blobel GA (2010) Role of the GATA-1/FOG-1/NuRD pathway in the expression of human beta-like globin genes. Mol Cell Biol 30:3460-3470.

Miccio A, Wang Y, Hong W, Gregory GD, Wang H, Yu X, Choi JK, Shelat S, Tong W, Poncz M, Blobel GA (2010) NuRD mediates activating and repressive functions of GATA-1 and FOG-1 during blood development. EMBO J 29:442-456.

Nagarajan R, Svaren J, Le N, Araki T, Watson M, Milbrandt J (2001) EGR2 mutations in inherited neuropathies dominant-negatively inhibit myelin gene expression. Neuron 30:355-368.

Nave KA, Trapp BD (2008) Axon-glial signaling and the glial support of axon function. Annu Rev Neurosci 31:535-561.

Nishioka K, Chuikov S, Sarma K, Erdjument-Bromage H, Allis CD, Tempst P, Reinberg D (2002) Set9, a novel histone $\mathrm{H} 3$ methyltransferase that facilitates transcription by precluding histone tail modifications required for heterochromatin formation. Genes Dev 16:479-489.

Parkinson DB, Bhaskaran A, Droggiti A, Dickinson S, D’Antonio M, Mirsky R, Jessen KR (2004) Krox-20 inhibits Jun-NH2-terminal kinase/c-Jun to control Schwann cell proliferation and death. J Cell Biol 164:385-394.

Parkinson DB, Bhaskaran A, Arthur-Farraj P, Noon LA, Woodhoo A, Lloyd AC, Feltri ML, Wrabetz L, Behrens A, Mirsky R, Jessen KR (2008) c-Jun is a negative regulator of myelination. J Cell Biol 181:625-637.

Pegoraro G, Misteli T (2009) The central role of chromatin maintenance in aging. Aging (Albany NY) 1:1017-1022.

Pereira JA, Baumann R, Norrmén C, Somandin C, Miehe M, Jacob C, Lühmann T, Hall-Bozic H, Mantei N, Meijer D, Suter U (2010) Dicer in Schwann cells is required for myelination and axonal integrity. J Neurosci 30:6763-6775.

Ramírez J, Hagman J (2009) The Mi-2/NuRD complex: a critical epigenetic regulator of hematopoietic development, differentiation and cancer. Epigenetics 4:532-536.

Russo MW, Sevetson BR, Milbrandt J (1995) Identification of NAB1, a repressor of NGFI-A and Krox20 mediated transcription. Proc Natl Acad Sci U S A 92:6873-6877.

Scherer SS, Wrabetz L (2008) Molecular mechanisms of inherited demyelinating neuropathies. Glia 56:1578-1589.

Scherer SS, Wang DY, Kuhn R, Lemke G, Wrabetz L, Kamholz J (1994) Axons regulate Schwann cell expression of the POU transcription factor SCIP. J Neurosci 14:1930-1942.

Srinivasan R, Mager GM, Ward RM, Mayer J, Svaren J (2006) NAB2 represses transcription by interacting with the CHD4 subunit of the NuRD complex. J Biol Chem 281:15129-15137.

Svaren J, Sevetson BR, Apel ED, Zimonjic DB, Popescu NC, Milbrandt J (1996) NAB2, a corepressor of NGFI-A (Egr-1) and Krox20, is induced by proliferative and differentiative stimuli. Mol Cell Biol 16:3545-3553.

Topilko P, Schneider-Maunoury S, Levi G, Baron-Van Evercooren A, Chennoufi AB, Seitanidou T, Babinet C, Charnay P (1994) Krox-20 controls myelination in the peripheral nervous system. Nature 371:796-799.

Topilko P, Levi G, Merlo G, Mantero S, Desmarquet C, Mancardi G, Charnay P (1997) Differential regulation of the zinc finger genes Krox-20 and Krox-24 (Egr-1) suggests antagonistic roles in Schwann cells. J Neurosci Res 50:702-712.

Wang Y, Zhang H, Chen Y, Sun Y, Yang F, Yu W, Liang J, Sun L, Yang X, Shi L, Li R, Li Y, Zhang Y, Li Q, Yi X, Shang Y (2009) LSD1 is a subunit of the NuRD complex and targets the metastasis programs in breast cancer. Cell 138:660-672.

Wang Z, Zang C, Cui K, Schones DE, Barski A, Peng W, Zhao K (2009) Genome-wide mapping of HATs and HDACs reveals distinct functions in active and inactive genes. Cell 138:1019-1031. 
Williams CJ, Naito T, Arco PG, Seavitt JR, Cashman SM, De Souza B, Qi X, Keables P, Von Andrian UH, Georgopoulos K (2004) The chromatin remodeler Mi-2beta is required for CD4 expression and T cell development. Immunity 20:719-733.

Woodhoo A, Alonso MB, Droggiti A, Turmaine M, D'Antonio M, Parkinson DB, Wilton DK, Al-Shawi R, Simons P, Shen J, Guillemot F, Radtke F, Meijer D, Feltri ML, Wrabetz L, Mirsky R, Jessen KR (2009) Notch controls embryonic Schwann cell differentiation, postnatal myelination and adult plasticity. Nat Neurosci 12:839-847.

Ye F, Chen Y, Hoang T, Montgomery RL, Zhao XH, Bu H, Hu T, Taketo MM, van Es JH, Clevers H, Hsieh J, Bassel-Duby R, Olson EN, Lu QR (2009) HDAC1 and HDAC2 regulate oligodendrocyte differentiation by disrupting the beta-catenin-TCF interaction. Nat Neurosci 12:829-838.
Yoshida T, Hazan I, Zhang J, Ng SY, Naito T, Snippert HJ, Heller EJ, Qi X, Lawton LN, Williams CJ, Georgopoulos K (2008) The role of the chromatin remodeler Mi-2beta in hematopoietic stem cell self-renewal and multilineage differentiation. Genes Dev 22:1174-1189.

Yun B, Anderegg A, Menichella D, Wrabetz L, Feltri ML, Awatramani R (2010) MicroRNA-deficient Schwann cells display congenital hypomyelination. J Neurosci 30:7722-7728.

Zegerman P, Canas B, Pappin D, Kouzarides T (2002) Histone H3 lysine 4 methylation disrupts binding of nucleosome remodeling and deacetylase (NuRD) repressor complex. J Biol Chem 277:11621-11624.

Zorick TS, Syroid DE, Brown A, Gridley T, Lemke G (1999) Krox-20 controls SCIP expression, cell cycle exit and susceptibility to apoptosis in developing myelinating Schwann cells. Development 126:1397-1406. 